\title{
Meningkatkan Motivasi dan Hasil Belajar Matematika dengan Metode Kooperatif Tipe Jigsaw di SMA Negeri 1 Gerung
}

\author{
Raden Roro Sri Heryekti Pujingsih \\ SMA Negeri 1 Gerung, Kabupaten Lombok Barat NTB \\ Corresponding Author. Email: heryekti1@gmail.com
}

\begin{abstract}
This study aims to improve motivation and mathematics learning outcomes through the application of the jigsaw cooperative learning model for class X-4 students at SMA Negeri 1 Gerung. This research method uses classroom action research. The research subjects were students of class X-4 with a total of 36 students. The research procedure was carried out on a cycle basis. Each cycle consists of planning activities, implementing actions, observing, and reflecting activities. The instruments used to collect research data consisted of tests and observation sheets. The research data were analyzed descriptively by using a percentage to see the trends that occurred in learning activities. The results showed that; (1) the application of the jigsaw cooperative learning model can increase student motivation in the teaching and learning process, (2) student motivation shows that in cycle 1 is $75 \%$ and an increase in cycle 2 becomes $84.7 \%$; and (3) students' mastery of the learning material also showed satisfactory results, in cycle 1 students achieved $77.8 \%$ completeness, while in cycle 2 students achieved $88.9 \%$ completeness.
\end{abstract}

\begin{abstract}
Abstrak: Penelitian ini bertujuan untuk meningkatkan motivasi dan hasil belajar matematika melalui penerapan model pembelajaran koperatife tipe jigsaw pada siswa kelas X-4 di SMA Negeri 1 Gerung. Metode penelitian ini menggunakan penelitian tindakan kelas. Subyek penelitiannya adalah siswa kelas X-4 dengan jumlah siswa sebanyak 36 orang. Prosedur penelitian dilakukan secara bersiklus. Pada setiap siklusnya terdiri dari kegiatan-kegiatan perencanaan, pelaksanaan tindakan, pengamatan, dan kegiatan refleksi. Instrumen yang digunakan untuk mengumpulkan data penelitian terdiri dari tes dan lembar observasi. Data penelitian dianalisis secara deskriptif dengan menggunakan persentase untuk melihat kecenderungan yang terjadi dalam kegiatan pembelajaran. Hasil penelitian menunjukkan bahwa; (1) penerapan model pembelajaran koperatife tipe jigsaw dapat meningkatkan motivasi siswa dalam proses belajar mengajar, (2) motivasi siswa terlihat bahwa pada siklus 1 adalah $75 \%$ dan mengalami kenaikan pada siklus 2 menjadi 84,7\%; dan (3) penguasaan siswa terhadap materi pembelajaran juga menunjukkan hasil yang memuaskan, pada siklus 1 siswa yang mencapai ketuntasan $77,8 \%$, sedangkan pada siklus 2 siswa yang mencapai ketuntasan $88,9 \%$.
\end{abstract}

Article History

Received: 03-12-2020

Revised: 23-12-2020

Published: 07-01-2021

Key Words:

Motivation, Learning

Outcomes, Jigsaw.

\section{Sejarah Artikel}

Diterima: 03-12-2020

Direvisi: 23-12-2020

Diterbitkan: 07-01-2021

\section{Kata Kunci:}

Motivasi, Hasil Belajar, Jigsaw.

How to Cite: Heryekti Pujingsih, R. (2021). Meningkatkan Motivasi dan Hasil Belajar Matematika dengan Metode Kooperatif Tipe Jigsaw di SMA Negeri 1 Gerung. Jurnal Paedagogy, 8(1). doi:https://doi.org/10.33394/jp.v8i1.3196

\section{Pendahuluan}

Pada era globalisasi yang terus berkembang, dunia pendidikan merupakan salah satu bidang yang menjadi sorotan dari berbagai kalangan, pendidikan adalah modal dasar yang harus dimiliki oleh semua insan karena dengan latar belakang pendidikan yang baik akan menunjukkan insan yang baik pula. Hal ini sesuai dengan pendapat Istiarsono (2016), yang menyatakan sikap yang paling bijaksana menghadapi globalisasi adalah mempersiapkan diri sebaiknya sehingga dapat memanfaatkan peluang yang terbuka didalamnya. Dalam persiapan itulah sektor pendidikana sangat penting untuk mencetak produk sumber daya manusia 
indonesia yang dapat menghadapi arus perubahan zaman. Salah satu kecakapan dasar yang harus dimiliki oleh siswa adalah kecakapan matematika (Hartati, 2015). Matematika merupakan ilmu dasar yang harus dikembangkan dan dipelajari oleh semua siswa, matematika sangat diperlukan dalam berbagai bidang, dari pertukangan, perdagangan, perindustrian, perkantoran bahkan jual beli dipasar tradisionalpun menggunakan matematika, tidak ada satu bidangpun didunia ini yang bisa terlepas dari perhitungan matematika, tetapi yang menjadi permasalahan disini justru matematika merupakan pelajaran yang tidak disukai sebagian besar siswa, matematika dianggap sebagai mata pelajaran yang sangat sulit (Siregar, N.R., 2017).

Pada zaman yang serba modern, serba canggih dimana apapun yang kita ingin cari dan ingin ketahui dapat dengan mudah kita peroleh hanya menggunakan HP tanpa kita harus bersusah payah justru kita temui sesuatu yang sangat ironi dimana kemajuan teknologi ini tidak diikuti dengan perubahan cara pembelajaran di kelas, masih banyak kita temui cara pembelajaran tradisional, siswa hanya menunggu apa yang diberikan dan disuruh gurunya, guru merupakan sumber ilmu, disini pembelajaran cederung satu arah, gurunya aktif sedangkan siswanya pasif (Nugroho, U., \& Edi, S. S. 2009). Kemajuan teknologi yang begitu pesat tidak menumbuhkan motivasi bagi siswa agar dapat mengembangkan materi pembelajaran secara mandiri sebaliknya dengan kecanggihan teknologi membuat siswa disibukkan dengan Hpnya meskipun itu saat pembelajaran sedang berlangsung hal ini sesuai dengan penyataan Fadilah, A. (2011) yang menyatakan : handphone merupakan alat komunikasi yang memberikan manfaat, handphone juga mempunyai aspek negatif yang merugikan kehidupan manusia.

Dari hasil analisis nilai ulangan semester ganjil kelas X-4 SMA Negeri 1 Gerung terlihat bahwa nilai rata-rata pelajaran matematika lebih rendah $(78,3)$ dibandingkan dengan mata pelajaran yang lain $(83,2)$. Berbagai upaya telah dilakukan oleh pemerintah untuk meningkatkan mutu penddidikan baik melalui pelatihan untuk guru maupun perubahan kurikulum, namun semua itu tidaklah berarti tanpa adanya kesadaran pribadi guru untuk merubah cara mengajar sesuai dengan materi, situasi dan kondisi sekitar. Guru bertanggungjawab terhadap keberhasilan siswa tidak hanya dari segi nilai, tetapi guru harus dapat menciptakan proses pembelajaran yang sesuai dengan yang diharapkan pemerintah seperti yang tercantum dalam PP nomor 19 tahun 2005 tentang Standar Nasional Pendidikan bab IV pasal 19 ayat 1 yang menyatakan bahwa proses pembelajaran pada satuan pendidikan diselenggarakan secara interaktif, inspiratif, menyenangkan, menantang memotivasi siswa untuk aktif serta memberikan ruang yang cukup bagi prakarsa, kreatif, sesuai dengan bakat, minat dan perkembangan fisik serta psikologis siswa.

Metode kooperatif tipe jigsaw merupakan salah satu metode pembelajaran yang mengelompokkan siswa dalam kelompok kecil (4-5 siswa) perkelompok, dimana pada kelompok ini setiap siswa akan bekerjasama dan bertanggungjawab atas keberhasilan semua anggota kelompoknya, pembelajaran dengan metode jigsaw akan membuat suasana pembelajaran menjadi aktif, kreatif dan menyenangkan. Isjoni (2011) menyatakan: jigsaw merupakan salah satu tipe pembelajaran kooperatif yang mendorong siswa aktif dan membantu dalam menguasai materi pelajaran untuk mencapai prestasi yang maksimal.

Berdasarkan dari berbagai masalah yang melatarbelakangi pembelajaran matematika seperti yang sudah diungkapkan sebelumnya dilakukan penelitian terkait pembelajaran matematika, sehingga siswa dapat mengembangkan kreatifitas, meningkatkan motivasu belajar, dan dapat meningkatkan hasil belajar. Karena itu implementasi model pembelajaran kooperatif tipe jigsaw diharapkan dapat dijadikan sebagai model yang tepat untuk 
menyelesaikan permaslahan pembelajaran matematika. Sehubungan dengan hal tersebut, dilakukan penelitian tindakan kelas yang bertujuan untuk meningkatkan motivasi dan hasil belajar matematika siswa kelas X-4 yang ada di SMA Negeri 1 Gerung.

\section{Metode Penelitian}

Metode penelitian ini menggunakan penelitian tindakan kelas yang dilaksankan di SMA Negeri 1 Gerung Kabupaten Lombok Barat pada mata pelajaran matematika. Subjek penelitiannya adalah siswa kelas X-4 yang berjumlah 36 orang terdiri dari 20 siswa perempuan dan 16 laki-laki. Prosedur penelitian ini dilakukan dengan mengacu pada implementasi penelitian tindakan kelas yang dilakukan secara bersiklus. Pada setiap siklusnya terdiri dari kegiatan-kegiatan perencanaan, pelaksanaan tindakan, pengamatan, dan kegiatan refeksi. Kegiatan yang dilakukan pada tahap perencanaan terdiri dari (1) melakukan analisis kurikulum untukmengetahui kompetensi dasar yang akan disampaikan kepada siswa, (2) membuat rencana pembelajaran kooperatif tipe jigsaw, (3) membuat lembar kerja siswa, (4) membuat instrumen yang digunakan dalam siklus penelitian tindakan kelas, (5) menyusun alat evaluasi pembelajaran, dan (6) menyusun daftar nama kelompok diskusi yang heterogen.

Pada tahap pelaksanaan tindakan dilakukan beberapa kegiatan, diantaranya ialah (1) melakukan pembagian kelompok diskusi yang akan dilakukan oleh siswa, (2) menyajikan materi pelajaran, (3) memberikan materi diskusi, (4) memfasilitasi diskusi kelompok, (5) mempresentasikan hasi diskusi kelompok siswa, (6) memberikan kuis atau pertanyaaan, (7) memberikan kesempatan siswa untuk memberikan tanggapan, (8) memberikan penguat dan kesimpulan bersama-sama siswa, dan (9) melakukan pengamatan observasi

Instrumen yang digunakan untuk mengumpulkan data penelitian terdiri dari tes dan lembar observasi. Tes digunakan untuk mengumpulkan data yang terkait dengan hasil belajar, tes ini diberikan pada saat siswa menyelesaikan kegiatan pembelajaran, sementara itulembar observasi digunkan untuk melakukan kegiatan pengamatan partisipasi siswa selama proses pembelajaran berlangsung.

Data penelitian dianalisis ini secara diskritif dengan menggunakan persentase untuk melihat kecenderungan yang terjadi dalam kegiatan pembelajaran. Data hasil belajar dan motivasi dikategorikan ke dalam tinggi, sedang dan rendah yang didasarkan pada nilaiulangan rata-rata harian. Sedangkan tingkat keberhasilan implementasi model pembelajaran kooferatife tife jigsaw dalam kegiatan pembelajaran dikategorikan dalam klasifikasi berhasil, kurang berhasil dan tidak berhasil. Penelitian ini dikatakan berhasil apabila $\geq 75 \%$ siswa aktif dalam pembelajaran, dan $\geq 75 \%$ siswa memperoleh nilai $\geq$ KKM.

\section{Hasil Penelitian dan Pembahasan Deskripsi Penelitian Siklus 1}

Hasil observasi proses pembelajaran pada siklus 1 memberrikan beberapa informasi, diantaranya ialah (1) Siswa masih binggung dan gaduh dalam mencari kelompoknya hal ini disebabkan masing-masing siswa memiliki dua kelompok yaitu kelompok asal dan kelompok ahli, pada saat kumpul dengan kelompok asal siswa membagi materi sesuai yang diberikan guru, setelah itu siswa harus mencari teman darikelompok lain yang memiliki materi yang sama untuk didiskusikan, (2) siswa kurang memanfaatkan media pembelajaran (kerangka kubus), (3) Pada saat ada kelompok ahli yang sudah selesai diskusi ada beberapa siswa yang mengganggu kelompok lain, (4) Pada saat diskusi dikelompok awal ada beberapa siswa yang tidak dapat menyampaikan kepada temannya materi yang harus dikuasai padakelompok ahli, 
dan (5) Pada saat presentasi ada beberapa siswa yang masih malu-malu dan canggung menyampaikan hasil diskusi maupun saat mendapat pertanyaan dari teman maupun guru.

Hasil observasi motivasi siswa dalam PBM selama siklus 1 dapat dilihat pada tabel 1 . Hasil observasi motivasi siswa dalam kegiatan belajar mengajar pada siklus 1 sudah menunjukkan hasil yang baik, dimana pada tabel terlihat bahwa dari 36 siswa yang memiliki kategori kurang motivasi hanya 1 siswa $(2,78 \%), 20$ siswa $(55,56 \%)$ memiliki kategori motivasi yang baik dan sisanya 15 siswa $(41,6 \%)$ memiliki kategori motivasi sangat baik.

Tabel 1. Perolehan Skor Motivasi dalam PBM Siklus 1

\begin{tabular}{|l|l|l|l|}
\hline Skor (\%) & Frekuensi & Persentase & \multicolumn{1}{|c|}{ Keterangan } \\
\hline $0-25$ & 0 & 0 & Kurang \\
\hline $26-50$ & 1 & 2.78 & Cukup \\
\hline $51-75$ & 20 & 55.56 & Baik \\
\hline $76-100$ & 15 & 41.67 & Sangat Baik \\
\hline Jumlah & 36 & 100 & \\
\hline
\end{tabular}

Hasil evaluasi penguasaan psiswa terhadap materi pembelajaran dalam proses PBM siklus 1 dapat dilihat pada tabel 2. Berdasarkan informasi pada Tabel 2. Terlihat bahwa penguasaan siswa terhadap materi pembelajaran sudah cukup bagus. Hasil evaluasi menunjukkan sebagian besar siswa (28 siswa) telah memiliki nilai tuntas dan sebagian kecil (8 siswa) masih memiliki nilai belum tuntas.

Tabel 2. Hasil Evaluasi Siswa dalam PBM Siklus I

\begin{tabular}{|c|c|c|c|}
\hline Nilai Matematika & Banyak Siswa & Persentase & Keterangan \\
\hline $47-55$ & 1 & 2.78 & \multirow{3}{*}{$\begin{array}{l}\text { Tidak tuntas } 8 \\
\text { siswa }(22,2 \%)\end{array}$} \\
\hline $56-64$ & 4 & 11.11 & \\
\hline $65-73$ & 3 & 8.33 & \\
\hline $74-82$ & 11 & 30.56 & \multirow{3}{*}{$\begin{array}{l}\text { Tuntas } 28 \text { siswa } \\
(77,8 \%)\end{array}$} \\
\hline $83-91$ & 6 & 16.67 & \\
\hline $92-100$ & 11 & 30.56 & \\
\hline Jumlah & 36 & 100 & $100 \%$ \\
\hline
\end{tabular}

Perolehan data penelitian pada Tabel 1 dan Tabel 2 menujukkan bahwa indikator keberhasilan dalam penelitian ini masih belum tercapai. Ketidakberhasilan ini disebabkan oleh beberapa faktor diantaranya ialah (1) Pada awal siklus kondisi pembelajaran masih belum kondusifsiswa masih ribut terutama pada saat pertukaran kelompok, (2) Sebagian siswa masih belum memahami langkah-langkah pembelajaran dengan metode kooperatife tife jigsaw, sehingga siklus I yang seharusnya selesai dalam dua pertemuan tetapi menjadi tiga pertemuan, (3) Masih ada kelompok yang memiliki alat peraga tetapi tidak dimanfaatkan secara maksimal sehingga saat presentasi mengalami kesulitan (saat mendapat pertanyaan dari siswa maupun guru), (4) Hasil observasi pada akhir siklus I sudah menunjukkan hasil yang baik meskipun masih ada 1 siswa yang memiliki motivasi kategori cukup, dan (5) Hasil evaluasi sudah mencapai nilai rata-rata diatas KKM meskipun masih ada 8 siswa yang masih belum tuntas.

Dalam mengatasi permasalah-permaslahan yang ditemukan pada siklus 1, dilakukan beberapa hal pada siklus 2. Beberapa hal tersebut 1alah (1) Guru dengan intensif memberi 
pengertian kepada siswa, kondisi dalam kelompok, kerjasama dalam kelompok, serta tugas dan kewajiban siswa dalam kelompok asal maupun kelompok ahli, (2) Guru membantu kelompok-kelompok yang mengalami kesulitan dalam menggunakan alat peraga, (3) Guru membantu kelompok yang belum memahami langkah-langkah pembelajaran koopetif tipe jigsaw, (4) Guru lebih intensif membimbing kelompok yang mengalami kesulitan dalam pemahaman materi, dan (5) Guru memberikan pengakuan atau penghargaan (reward).

\section{Deskripsi Penelitian Siklus 2}

Hasil observasi proses pembelajaran pada siklus 2 memberikan beberapa informasi, diantaranya ialah (1) Siswa sudah memahami model pembelajaran kooferatif tife jigsaw, pembagian kelompok sudah mulai tertib dan suasana tidak gaduh dalam mencari kelompoknya (siswa tinggal menuju meja yang sudah disiapkan untuk kelompoknya), (2) Siswa dalam satu kelompok menunjukkan sikap saling membantu untuk menguasai materi pelajaran yang diberikan melalui tanya jawab atau diskusi antara sesama anggota kelompok, (3) Semua siswa terlihat aktif dalam pembelajaran, suasana efektif dan menyenangkan sudah terlihat.

Hasil observasi motivasi siswa dalam PBM selama siklus 2 dapat dilihat pada table 3. Hasil observasi siswa pada siklus 2 sudah menunjukka hasil yang baik. Hasil penelitian pada Tabel 3 menunjukkan bahwa semua siswa telah memiliki motivasi baik, dimana dari 36 siswa 9 siswa (25\%) memiliki motivasi kategori baik dan 27 siswa (75\%) memiliki motivasi sangat baik. Hal ini menunjukkan adanya peningkatan yang sangat signifikan dibandingkan hasil penelitian siklus 1 .

Tabel 3. Hasil Observasi Motivasi Siklus 2

\begin{tabular}{|l|l|l|l|}
\hline \multicolumn{1}{|c|}{ Skor $\mathbf{( \% )}$} & Frekuensi & Persentase $\mathbf{( \% )}$ & Keterangan \\
\hline $0-25$ & 0 & 0 & \\
\hline $26-50$ & 0 & 0 & \\
\hline $51-75$ & 9 & 25 & Baik \\
\hline $76-100$ & 27 & 75 & Sangat Baik \\
\hline Jumlah & 36 & 100 & \\
\hline
\end{tabular}

Hasil evaluasi penugasaan siswa terhadap materi pembelajaran dalam proses PBM siklus 2 dapat dilihat dalam table 4 yang menunjukka bahwa penguasaan siswa terhadap materi pembelajaran sudah bagus. Hasil evaluasi menunjukkan sebagian besar siswa (32 siswa) telah memiliki nilai tuntas dan sebagian kecil (4 siswa) masih memiliki nilai belum tuntas.

Tabel 4. Hasil Evaluasi Materi Pembelajaran Siklus 2

\begin{tabular}{|l|l|l|l|}
\hline Nilai Matematika & Banyak Siswa (f) & Persentase & Keterangan \\
\hline $59-65$ & 4 & 11.11 & $\begin{array}{l}\text { Tidak tuntas } \\
\text { siswa }(11,1 \%)\end{array}$ \\
\hline $66-72$ & 0 & 0.00 & $\begin{array}{l}\text { Tuntas 32 siswa } \\
(88,9 \%)\end{array}$ \\
\hline $73-79$ & 6 & 16.67 & \\
\cline { 1 - 2 } $80-86$ & 14 & 38.89 & \\
\hline $87-93$ & 8 & 22.22 & \\
\hline $94-100$ & 4 & 11.11 & \\
\cline { 1 - 2 } Jumlah & 36 & 100 & \\
\hline
\end{tabular}


Perolehan data penelitian yang tercantum pada tabel 3 dan tabel 4 menunjukkan bahwa indikator keberhasilan dalam penelitian ini sudah tercapai. Ketercapaian indikator keberhasilan ini disebabkan oleh beberapa faktor. Faktor-faktor tersebut diantaranya ialah (1) Aktivitas siswa dalam proses belajar mengajar sudah mengarah ke pembelajaran kooperatife tipe jigsaw. Siswa sudah memahami langkah-langkah metode kooperatife tipe jigsaw sehingga mereka dapat membangun kerjasama yang baik dalam kelompok untuk dapat memahami tugas atau materi yang diberikan. Siswa mulai mampu berpartisipasi dalam kegiatan dan tepat waktu dalam melaksanakannya, sehingga jadwal pertemuan siklus 2 yang ditetapkan dua kali pertemuan bisa dilaksanakan, berbeda dengan siklus pertama yang tidak sesuai jadwal, (2) Meningkatnya Observasi motivasi siswa juga berdampak terhadap keberhasilan siswa. Pada siklus pertama 7 siswa $(19,44 \%)$ tidak tuntas dan pada siklus ke dua mengalami perubahan 4 siswa $(11,11 \%)$ tidak tuntas. Adapun hasil penelitian ini juga didukung oleh hasil penelitian yang dilakukan oleh Nirta (2019), Fajuri (2019), Nashirotun, Asni (2017), dan Pratini (2015) yang menyimpulkan bahwa penerapan model pembelajaran kooperatif tipe jigsaw telah mampu meningkatkan aktivitas, motivasi dan hasil belajar siswa.

\section{Kesimpulan}

Berdasarkan hasil penelitian ini dapat disimpulkan bahwa; (1) Penerapan pembelaaaran kooperatif tipe jigsaw dapat meningkatkan motivasi siswa dalam proses belajar mengajar; (2) Dari Hasil observasi motivasi siswa terlihat bahwa pada siklus pertama $75 \%$ sedangkan pada siklus ke dua 84,7\%; (3) Penguasaan siswa terhadap materi pembelajaran juga menunjukkan hasil yang memuaskan pada siklus 1 siswa yang mencapai ketuntasan $77,8 \%$, sedangkan pada siklus 2 siswa yang mencapai ketuntasan $88,9 \%$.pertama nilai rataratanya mencapai 82,5 sedangkan pada siklus ke dua nilai rata-ratanya mencapai 82,61 . Nilai rata-ratanya melebihi nilai KKM yaitu 7,5.

\section{Saran}

Adapun saran yang disampaikan berdasarkan hasil penelitian ini adalah bagi guru lainnya agar dapat menerapkan model pembelajaran kooperatif tipe jigsaw ini sesuai dengan mata pelajaran yang diampu dengan melakukan modifikasi dalam proses implementasinya.

\section{Daftar Pustaka}

Asni, H. (2017). Upaya Meningkatkan Aktivitas dan Hasil Belajar Peserta Didik Melalui Penerapan Pendekatan Cooperative Learning Tipe Jigsaw di Kelas III-A SD Negeri 2 Cakrangeara. Jurnal Kependidikan: Jurnal Hasil Penelitian dan Kajian Kepustakaan di Bidang Pendidikan, Pengajaran dan Pembelajaran, 3(2). doi:https://doi.org/10.33394/jk.v3i2.567

Daryanto. (2013). Inovasi Pembelajaran Efektif, Bandung : Y Rama Yuda

Fadilah, A. (2011). Pengaruh penggunaan alat komunikasi handphone (hp) terhadap aktivitas belajar siswa SMP negeri 66 Jakarta Selatan.

Fajuri, F. (2019). Penerapan Pendekatan Cooperative Learning Tipe Jigsaw dalam Upaya Meningkatkan Aktivitas dan Hasil Belajar Peserta Didik Kelas I SD Negeri 27 Ampenan. Jurnal Paedagogy, 6(1), 20-26. doi:https://doi.org/10.33394/jp.v6i1.2526

Hartati, L. (2015). Pengaruh gaya belajar dan sikap siswa pada pelajaran matematika terhadap hasil belajar matematika. Formatif: Jurnal Ilmiah Pendidikan MIPA, 3(3).

Isjon i(2011). Cooperative Learning Efektifitas Pembelajaran Kelompok, Bandung Alfabeta. 
Istiarsono, Z. (2016). Tantangan Pendidikan dalam Era Globalisasi: Kajian Teoretik. INTELEGENSIA , 1 (2).

Kunandar. 2008. Lankah mudah Penelitian Tindakan Kelas sebagai Pengembangan Profesi Guru, Jakarta : PT Rajagrafindo Persada.

Nashirotun, B. (2020). Peningkatan Aktivitas dan Hasil Belajar Siswa dengan Metode Jigsaw dan Media Tubuh Manusia pada Pembelajaran IPA di MTs. Negeri 4 Klaten Jawa Tengah. Jurnal Paedagogy, 7(4), 402-407. doi:https://doi.org/10.33394/jp.v7i4.2945

Nirta, I. (2019). Upaya Meningkatkan Aktivitas dan Hasil Belajar Peserta Didik Kelas IV SD Negeri 14 Cakranegara Melalui Penerapan Pendekatan Cooperative Learning Tipe Jigsaw. Jurnal Paedagogy, 6(1), 8-13. doi:https://doi.org/10.33394/jp.v6i1.2524

Nugroho, U., \& Edi, S. S. (2009). Penerapan pembelajaran kooperatif tipe STAD berorientasi keterampilan proses. Jurnal Pendidikan Fisika Indonesia, 5(2).

Pratini, P. (2015). Upaya Meningkatkan Aktivitas dan Hasil Belajar PKn Siswa Kelas VIII-B SMPN 18 Mataram Melalui Penerapan Pendekatan Cooperative Learning Tipe Jigsaw. Jurnal Kependidikan: Jurnal Hasil Penelitian dan Kajian Kepustakaan di Bidang Pendidikan, Pengajaran dan Pembelajaran, 1(2). doi:https://doi.org/10.33394/jk.v1i2.417

Siregar, N. R. (2017). Persepsi siswa pada pelajaran matematika: studi pendahuluan pada siswa yang menyenangi game. Prosiding Temu Ilmiah Nasional X Ikatan Psikologi Perkembangan Indonesia, 1. 